Beta-blockade and Myocardial Infarction

SIR,-We appreciate the reply of Dr. K. M. Fox and his colleagues (26 April, p. 193) to our letter (15 March, p. 627).

(1) We cannot accept that a prospective (randomized control, double-blind) trial of beta-blockers in patients with coronary heart disease would be unethical. Dr. Fox and his colleagues state that "the beneficial effects of beta-blockade for stable and unstable angina are now well proved and such a study would mean withholding this form of therapy from half the patients." Even if one studied only patients with angina, the faot that some patients appear to improve symptomatically on betablockade goes no way towards resolving the controversy as to whether such treatment alters montality. This controversy is our very reason for considering a prospective study both ethical and necessary.

(2) While we are grateful for the additional information about the comparability of Dr. Fox and his colleagues' control and beta-blocker groups, the possibility of a difference in prognostic composition of the two groups cannot be answered without prospective follow-up.

(3) We are sorry that Dr. Fox and his colleagues do not appear to understand the term "too 'soft' an end point." The duration of their patients' chest pain is irrelevant to the fact that "coronary insufficiency" remains an unconfirmed symptom. We do not understand how the fact that the definition of acute coronary insufficiency "varies throughout the literature" justifies the creation of new and potentially more confusing diagnostic terms.

(4) It is fortunate that the consecutive rather than random selection of controls may not have prejudiced the results of their study. We hope that Dr. Fox and his colleagues would concede that random selection of controls is preferable.

(5) The fact that our observaion that the acute myocardial infarction mortality appeared to be twice as high in the betablocked patients as in the control group "is not supported statistically" is not surprising in view of the small numbers of patients studied. The observation still stands and deserves further study with a larger group of patients.-We are, etc.

IAN M. GRAHAM NOEL HICKEY RISTEARD MULCAHY St. Vincent's Hospital and University College, Dublin

GIIbERT MacKENZIE

Queen's University,

Belfast

\section{Geriatric Admissions}

SIR,-Miss Mary Inglis (10 May, p. 338) quite correctly points out that the wishes of geriatric partients should be respected, but I do not agree that the geriatrician should be expected to prescribe "squalid" living conditions for them even if they have no desire for change. This view is taken because for them life becomes a struggle against increasing physical and mental disability leading to loneliness and social isolation giving rise to "rejeotion syndrome." If patients could be encouraged to be admitted to hospital as soon as required, many could return to satisfactory living conditions after treatment and enjoy a healthier and happier life.

It is unfortunate that some admissions to the geriatric unit are due to pressure from relatives or colleagues in acute specialties (as suggested by Miss Inglis), but it is important that the admission should be at a time when the patient needs it and not necessarily due to pressure from any person, because following rehabilitation many may return to the community. This, of course, can be done only if the facilities and staff are adequate. There is a great need to improve the standard of geriatric care, both in the hospital and the community. The present generation of elderly people were not fortunate enough to have a high standard of education in their early life, and their attitude towards medical care and authority is influenced by their experience of life in the past, which included economic hardship and two world wars. ${ }^{1}$ There is evidence that the present generation of people are getting more and more sophisticated in their demands for care in hospital and in the community and this will definitely increase further in the future.

It is true that the elderly patients should be free to decide things for themselves, but the profession cannot prescribe "squalid" living conditions even if some of the elderly would prefer it.-I am, etc.

t. Luke's Hospital

N. K. Chakravorty Huddersfield 1 Portsmouth, O. H. D., Modern Geriatrics, 1972 ,
$2,39$.

\section{Aetiology of Chronic Renal Failure and} Renal Osteodystrophy

SIR,-We have read the observations of Dr. J. A. Kanis and his colleagues (15 March, p. 628) with interest, particularly since they have compared our findings ( 7 December 1974 , p. 557) with their own and those of Pendras. ${ }^{1}$ Unfortunately, marked differences between these series and our own with respect to clinical management and method of analysis make comparison inappropriate. Pendras made no attempt to control plasma phosphate $(2 \cdot 2-3.0 \mathrm{mmol} / 1 \quad(6 \cdot 9-9 \cdot 3 \mathrm{mg} / 100$ $\mathrm{mi}$ )) whereals we have (average $1.45 \mathrm{mmol} / 1$ $(4.5 \mathrm{mg} / 100 \mathrm{ml})$ ). Dialysate calcium in Pendras's and the Oxford series was 1.5 mmol $/ 1(6.0 \mathrm{mg} / 100 \mathrm{ml})$, while the dialysate calcium in our patients has been $1.88 \mathrm{mmol} / 1$ $(7.5 \mathrm{mg} / 100 \mathrm{ml})$ for the past six years.

We thought that our observations with respect to the absence of erosions in nine male polycystic partients were of interest, firstly because this group, though small, was homogeneous with respeot to age, sex, and disease, and secondly, because none of the nine polycystics developed erosions over the six-year period of study. The 50 age-andsex-matched controls were, of course, heterogeneous with respect to the original kidney disease. It is still exceptionally difficult to define original diseases in dialysis patients so that the need emphasized by Dr. Kanis and his colleagues for comparison of the polycystics with homogeneous groups, though logical and undoubitedly well meant, is virtually impossible. They have attributed homogeneity to patients with interstitial nephnopathy diagnosed on history and radiology. However, these criteria are insufficient, since interstitial nephritis has at least 24 distinct aetiologies, many of which lead to chronic renal failure. ${ }^{2}$ In the circumstances of our clinical study we still feel that polycystic disease may protect against erosions, since erosions did not occur in this group and since age and sex were not responsible for their absence polyoystic disease might be. It has been suggested elsewhere ${ }^{3}$ that removal of polycystic kidneys on dialysis might cause an acute deficiency of 1,25-dihydroxycholecalciferol. It is possible that polycystic kidneys may have marginal capability for producing the active metabolite of vitamin $\mathrm{D}$ and hence for calcium absorption and protection against secondary hyperparathyroidism. Dialysis conditions are never ideal and vary considerably between units, so any advantage of polycystic disease may be lost by the use of low dialysate calcium, as in the Oxford patients.

In conclusion, afiter perusal of their short report ${ }^{4}$ and abstract $^{5}$ we agree that Dr. Kanis and his colleagues are bound to conclude that in their programme polycystic disease does not protect against erosions; however, in our own patients under different conditions a protective effeot may be hypothesized, provided age and sex are accounted for and the disease is uncomplicated by severe infection.-We are, etc.,

JOHN MOORHEAD G. L. W. TATLER STEPHEN FARROW R. A. BAILlOD Royal Free Hospital,

M. R. WIILS

\section{Pendras, J. P., Archives of Internal Medicine, 1969, 124, 312 \\ M. B. Strauss, and L. G. Welt the Kidney, ed. M. B. Strauss, and L. G.
Breun, vol. 1, p. 667,1971 . \\ Cheigh, J. S., et al., Urology, 1973, 2, 121 \\ Henderson, R. G., et al., Proceedings of the Royal Society of Medicine, 1974, 67, 38. \\ Henderson, R. G., Ledingham, J. G. G., and
Woods, G. G., Kidney International, 1974, 6, 62 .}

\section{Fatty Acid Composition of Adipose Tissue} in Newborn Infants

SIR,-Further to the article by Dr. Elsie M. Widdowson and others "Body Fat of British and Dutch Infants" (22 March, p. 653 ) in which significant differences are reported between British and Dutch infants at birth, we have made observations on 16 babies born in London in 1972 as part of a study on infant nutrition. ${ }^{1}$ Our values resemble those found in Dutch babies by Dr. Widdowson and her colleagues and differ from their findings in British babies.

We studied eight term light-for-dates babies (gestation 38 completed weeks, weight for gestational age below 10th centile), three preterm (36 weeks) light-for-dates babies, and five preterm (32-35 weeks) appnopriateweight-for-dates babies. The parents gave informed consent for sampling of adipose tissue from the baby's thigh using a no. 1 needle during the first day of life, and triglyceride was analysed as fatty acid methyl esters by gas chromatography. ${ }^{2}$ The table shows the fatty acid composition of the adipose tissue; the results of Dr. Widdowson and her colleagues and three American studies $^{3-5}$ are shown for comparison.

We do not know the reason for the difference between our findings and those reported by Dr. Widdowson and her col- 
Mean Adipose Tissue Fatty Acid Composition for Newborn Infants ( $g / 100 \mathrm{~g} \pm 1$ S.D.)

\begin{tabular}{|c|c|c|c|c|c|c|c|}
\hline \multirow[b]{2}{*}{ Fatty Acid } & & \multirow[b]{2}{*}{$\begin{array}{c}\text { London } \\
\text { (healthy, } \\
\text { all low } \\
\text { birth weight, } \\
\mathbf{n}=16 \text { ) }\end{array}$} & \multicolumn{2}{|c|}{ Widdowson et al. ${ }^{1}$} & \multirow[b]{2}{*}{$\begin{array}{c}\text { Hashim and } \\
\text { Asfour } \\
\text { (normal, } \\
\text { term, } \\
\text { n=15) }\end{array}$} & \multirow[b]{2}{*}{$\begin{array}{c}\text { King et al. }{ }^{3} \\
\text { (normal, } \\
\text { term, } \\
n=5)\end{array}$} & \multirow[b]{2}{*}{$\begin{array}{c}\text { Baker }^{5} \\
\text { (term, } \\
\text { post- } \\
\text { mortem, } \\
\mathbf{n}=5 \text { ) }\end{array}$} \\
\hline & & & $\begin{array}{c}\text { Dutch } \\
\text { (healthy, } \\
\text { some low } \\
\text { birth weight, } \\
\mathrm{n}=12 \text { ) }\end{array}$ & $\begin{array}{c}\text { British } \\
\text { (most } \\
\text { preterm, } \\
\text { post- } \\
\text { mortem, } \\
\mathrm{n}=14)\end{array}$ & & & \\
\hline $\begin{array}{l}\text { C14:0 (Myristic) } \\
\text { C16:0 (Palmitic) } \\
\text { C18:0 (Stearic) } \\
\text { C16:1 (Palmitoleic) } \\
\text { C18:1 (Oleic) } \\
\text { C18:2 (Linoleic) }\end{array}$ & $\begin{array}{l}\cdots \\
\cdots \\
\cdots \\
\cdots\end{array}$ & $\begin{array}{r}4 \cdot 4 \pm 0.9 \\
44.5 \pm 2 \cdot 7 \\
4 \cdot 4 \pm 1 \cdot 0 \\
14 \cdot 7 \pm 2 \cdot 0 \\
29 \cdot 7 \pm 1 \cdot 6 \\
2 \cdot 3 \pm 0.9\end{array}$ & $\begin{array}{r}3 \cdot 3 \pm 0 \cdot 4 \\
45 \cdot 8 \pm 1 \cdot 6 \\
3 \cdot 8 \pm 0 \cdot 4 \\
15 \cdot 2^{*} \pm 1 \cdot 2 \\
29 \cdot 0 \pm 1 \cdot 8 \\
2 \cdot 9^{*} \pm 0 \cdot 7\end{array}$ & $\begin{array}{r}3 \cdot 8 \pm 0 \cdot 6 \\
48 \cdot 9 \pm 3 \cdot 6 \\
4 \cdot 1 \pm 0.6 \\
12 \cdot 6^{*} \pm 1 \cdot 6 \\
29 \cdot 6 \pm 3 \cdot 0 \\
1 \cdot 0^{*} \pm 0.8\end{array}$ & $\begin{array}{r}3 \cdot 2 \pm 0 \cdot 8 \\
52 \cdot 0 \pm 3 \cdot 5 \\
4 \cdot 1 \pm 0 \cdot 8 \\
9 \cdot 5 \pm 1 \cdot 1 \\
30 \cdot 8 \pm 1.9 \\
0.8 \pm 0.7\end{array}$ & $\begin{array}{r}4 \cdot 4 \pm 0 \cdot 8 \\
48 \cdot 4 \pm 5 \cdot 4 \\
5 \cdot 7 \pm 2 \cdot 3 \\
13 \cdot 3 \pm 3 \cdot 0 \\
24 \cdot 8 \pm 2 \cdot 5 \\
1 \cdot 1 \pm 1 \cdot 1\end{array}$ & $\begin{array}{c}3.3 \\
38 \cdot 6 \\
4.5 \\
15.9 \\
33.5 \\
2.5 \\
\text { (no S.D.s } \\
\text { given) }\end{array}$ \\
\hline
\end{tabular}

$* \mathbf{P}<0.001$

leagues. We have no data on the fatty acids in the mothers of our infants, but in general these women belonged to the local workingclass community around Hackney. We believe they were unlikely to consume much polyunsaturated fat, which was one suggested reason for the higher linoleic acid $(\mathrm{C} 18: 2)$ levels found in the babies of Dutch mothers. There are, however, differences both in adipose tissue sampling and in chemical methodology. The Dutoh babies and our London babies had adipose tissue samples taken by needle biopsy soon after birth, whereas all except one sample of Dr. Widdowson's "British group" were from infants who had died perinatally. When one compares the values obtained in various American studies there are striking differences between the results which might, in part at least, reflect differing methodologies, whereas within the same study comparison of differing clinical groups of infants has usually not shown up chemical differences (for example, the study of King et al. ). $^{4}$.

There is, then, some variation in the reported fatty acid composition of adipose tissue at birth. This may reflect true biological variation but we feel that at least part of the variation is due to differing methodology.-We are, etc.,

AUDREY FOSBROOKE

Institute of Child Health BRIAN WHARTON

London W.C.1

1 Fosbrooke, A. S., and Wharton, B. A., Archives of Disease in Childhood. In press.

2 Fosbrooke, A. S., and Tamir, I., Clinica Chimica Acta, 1968, 20, 517.

3 King, K. C., et al., Pediatrics, 1971, 47, 192.

Hashim, S. A., and Asfour, R. H., American

5 Bournal of Clinical Nutrition, 1968, 21 , 7 .

Nutrition, 1969, 22, 829.

$$
)_{0} c^{2}
$$

\section{$\checkmark$ Scabies in a Spinal Injuries Ward}

SIR,-I was recently asked to investigate an outbreak of irritating papules on the forearms and thighs of nunsing staff in a spinal injuries wand. The eruption found in the case of eight nurses resembled that seen among ward staff in epidemics caused by cases of Norwegian scabies. No burrows could be found nor were mites isolated. Examination of the 20 patients in the ward revealed that five were heavily infested with Sarcoptes scabiei. All these patients had suffered fractures of cervical vertebrae 4,5 , 6 , or 7 with consequent loss of cutaneous sensation.

Paterson et al. ${ }^{1}$ writing on the development of Norwegian scabies during immunosuppressive therapy tabullated the aetio logical factors so far reponted in cases of
Norwegian scabies, among which was lack of cutaneous sensation occurring in leprosy, syringomelia, and tabes dorsalis. The scabies cases in this ward epidemic, though all presenting a massive infestation, in one at least amounting to many hundreds of mites, did not show the picture of Norwegian scabies. The trunk and limbs had profuse scattering of enythematous papules each surmounted by a typical burrow. There was, however, no hyperkeratosis or crusting. One young adult had multiple palmar burrows with minimal erythema similar to that frequently seen in very young infants. I suggest that the loss of cutaneous sensation following fracture of cervical ventebrae allowed unrestricted multiplication of mites owing to lack of itching and therefore scratching and that this tends to confirm Mellanby's observation ${ }^{2}$ that "in man it is the active finger nails of the host which keep down the parasite population." The duration of the infestation was unknown, probably only a few months, and this was presumably too shont to allow the development of the hyperkeratosis and crusting seen in true Norwegian scabies. The mites, however, were sufficiently numerous to result in a ward epidemic involving nursing staff. It was only this involvement of staff with intact sensation that led to detection of the infestation.

Treatment with $1 \%$ gamma benzene hexachlloride (Quellada lotion) was rapidly effective with no case of failure to respond. -I am, etc.

\section{R. Workman Carslaw}

Department of Dermatology,

Victoria Hospital,

1 Paterson, W. D., Allen, B. R., and Beveridge, 2 Mellanby, K K., Scabies. Hampton, Middlesex,

\section{Operator/Anaesthetists}

SIR,-With the declaration of the President of the General Dental Council on the subject of operator/anaesthetists (24 May, p. 453) dentists now know that they will be judged to be guilty of infamous professional conduct if they act in that capacity.

Will the B.M.A. approach the General Medical Council for a ruling relating to doctors acting as operator/anaesthetists? While this practice is not widespread, it certainly does happen-for example, psychiatrists performing electric convulsion therapy and thoracic surgeons performing bronchoscopy under intravenous barbiturate plus a muscle relaxant, physicians performing gastroscopy under intravenous anaes- thetic doses of diazepam, general practitioners opening abscesses etc. under "a whiff of gas." Even the anaesthetist himself assumes the dual role if he first anaesthetizes the patient then proceeds to the rear to perform caudal or lumbar epidural puncture and catheterization.-I am, etc.,

London W.4

DONALD BLATChIEY

Practolol, Indoramin, and Asthma

SIR,-I.C.I. have recently circulated new prescribing information about practolol recommending that in view of its side effects its use should be limited to patients with organic cardiac disease and those with asthma or bronchitis.

Practolol is cardioselective and is less likely to cause bronchospasm than other beta-blockers, but patients with asthma ofiten do get a troublesome increase in wheeziness if given the drug. We have recently been looking at the effect of combining practolol with the alpha-adrenergic blocker indoramin hydrochloride in patients with asthmma and angina to see if pretreatment with the alphablocker would prevent the effect of betablockade on the bronchial tree.

Six patients suffering from reversible airways obstruction and angina were studied. They were observed for one control week, then given one week on practolol $100 \mathrm{mg}$ twice daily, one week on indoramin $20 \mathrm{mg}$ three times daily, and one week on a combination of the two drugs. They kept diary cards and measured their own peak expiratory flow rate (P.E.F.R.) twice daily throughout. Four of the six complained of increased wheezing with practolol and two had to stop the drug. The average drop in P.E.F.R. for all six was $11 \%$ (range $+3 \%$ to $-37 \%$ ). During the week on indoramin alone there was subjective improvement in both asthma and angina. When practolol was reintroduced the four patients who had complained of wheezing before were again affected and all four stopped the drug. The average drop in P.E.F.R compared with control was $19 \%$ (range $-6 \%$ to $-50 \%$ ).

The combination of these drugs appeared to make the bronchospasm worse. A possible explanation is that with blockage of alpha and beta adrenoceptors the cholinergic innervation was left unopposed.

Little has been reponted about increased airways obstruction in asthmatios on practolol since the early studies,' but clinical experience and the observations above show that it may be a greater problem than at first suggested.-We are, etc.

ELISABETH PAICE Tindal General Hospital,
Aylesbury, Bucks E. S. EL HASSAN

1 Macdonald, A. G., and McNeill, R. S., British Fournal of Anaesthesia, 1968, 40, 508 .

\section{Milk pH and Gastroenteritis in Newborn Infants}

SIR,-Harrison and Peat ${ }^{1}$ reported that feeding full-term normal newborn infants with a humanized cow's milk (Similac) that had been allkalinized to pH $7 \cdot 2$ produced a stool of low pH (mean 5.5), of reduced buffering capacity, and a bacterial flora of predominantly Lactobacillus bifidus. The infants tended to regain their birth weight earlier than a control group on non-allkalized Similac. Realizing that if these findings were confirmed the feeding of such an alkalinized 